\title{
Leveraging, Capture and Resistance: Local Adaptation of the Discourse on European Cohesion Policies in Italian Regions
}

\author{
LUCA PARESCHI \\ luca.pareschi@uniroma2.it \\ Tor Vergata University of Rome
}

\begin{abstract}
Cohesion policy accounts for more than one third of the budget of the European Union, but research mostly focuses on economic aspects. In this paper we tackle the discursive dimension of cohesion policy, and in particular, we address the debate on newspapers at national and regional level. As regions can be deemed as the product of struggle over meaning, and as discourses are able to mould and change reality and how we perceive it, we explore the topics used by media when dealing with Cohesion Policy, and in particular we address to what extent national and regional debate differ, also considering regions that differ according to the effectiveness of funds' management. We performed a topic model on newspapers articles, and we also collected economic data through Eurispes. Our findings point at three processes, which we called leverage, capture, and resistance, which define the local (regional) adaptation of national discourses on cohesion policy. These processes reflect entrenched power relations and depend on the specific context of programming periods, on contingent events, and on structural factors pertaining to regions' history of economic and social development.
\end{abstract}

\section{Introduction}

Cohesion Policy accounts for more than one third of the budget of the European Union ${ }^{1}$, and aims at facilitating the converge of economic development of European regions. While the economic dimension of Cohesion Policy (i.e., the rate of absorption by different regions) is tackled by academic literature, the discursive dimension of Cohesion Policy remains overlooked. This is particularly relevant, as regions can be conceived as the result of struggles over symbolic meanings in different social field (Passi, 2001). Several scholars emphasise the relationship between power and discourse (i.e., Foucault, 1972; Bourdieu, 1991, Habermas, 1981): although they do not agree on the freedom of strategic action for the social agents, there is agreement on the fact that discourses are endowed with the performative power to define and change reality. Therefore, discourses around regions impact the same definition of regions. We are particularly interested in how discourses about regions and cohesion policy change by shifting from lower to higher levels of locality. Cohesion Policy are particularly interesting, as: first, they are defined centrally, at the level of European Commission, and implemented locally, at the level of European regions. This structure creates a complex political field that extend from Brussels to national governments, to local administrations in

\footnotetext{
${ }^{1}$ https:/ec.europa.eu/regional_policy/en/policy/what/investment-policy/
} 
regional areas. Within this layered structure, Brussels bears the budgetary costs of cohesion policies and local administrations are responsible for their implementation. Second, cohesion policies represent valuable economic opportunities for regions, and funds allocation to regions may influence local interests and mobilise specific interest groups. A question emerges on whether the mobilisation of economic interests influences local discourses.

European Public Sphere refers to the idea that the same issues are debated at the same time, in different European countries, through the same categories. But many scholars suggest (Risse, 2003; 2009) that a proper European Public Sphere is still underdeveloped or populated solely by European political, economic and intellectual elites. Thus, the discourse on the policies of the European Union is especially limited to a cosmopolitan, elitist arena. National media differ according to the way they treat European issue, which usually are not relevant for European voters (Moravcsik, 2002); these issues tend to interact with local issues and local discourses. This consideration leads us to our research questions: What are the topics used by media when dealing with Cohesion Policy? And to what extent do national and regional debate differ, also considering regions that differ according to the effectiveness of funds' management?

To address these questions, we performed topic modelling on journal articles in a sample of regions in which the implementation of cohesion policies yielded different results. In particular, we focus on the Italian case as our empirical context, as Italian regions differ according to the effectiveness of implementation and communication of Cohesion Policy, and as Italian regions are differently categorised as convergence or competition regions. We inspected one journal, La Repubblica, and we compared the national edition and the local editions to address the different layers of debate. We selected a journal that is widely diffused in Italy, and that publishes a good number of high-quality local editions.

We address the attempt of local political discourses to maintain their autonomy within larger discourses. In particular, our findings point at how local discourses may be captured and moulded by three groups of elements that reflect entrenched power relations. First, we looked at factors connected to the specific context of programming periods - transparency and effectiveness of local authorities in managing local funds -. Second, we considered contingent events taking place in the programming periods (cases of frauds, natural plagues or other salient events). Finally, we contemplated structural factors pertaining to regions' history of economic and social development as crystallised by the classification as convergence or competition objectives.

Theoretically, our research is new as, whereas previous studies on European political discourse addressed the adaptation of European issue fields into national mass media (Adam, 2007), we go further by analysing how regional media adapt to nationally covered European issues. The paper is structured as follows: the next three paragraphs review the concepts of power and discourse, the relevance of mass media within the European Public Sphere, and present the context of Cohesion Policy. Then we present method and data. Results on both discursive and contextual dimension of Cohesion Policy lead to the discussion and, finally, to the conclusion.

\section{Discourse, power and regions as social constructs}

According to Foucault, discourse is the locus of power (Foucault, 1972): discourse assigns power, and subject positions reveals power relations. Also, in Bourdieu (1986, 1990, 1991), 
discourses provide the arena in which power relations emerge. In his work, the very measure of power - symbolic power - is the power defining the legitimation to speak. The concept of symbolic capital is the central point of Bourdieu's analysis of power: symbolic power grants the power to nominate or the monopoly of legitimate naming, that is, the power to create the world through naming. (Bourdieu, 1991). Thus, symbolic capital endows with a sort of "performative magic" (Bourdieu, 1991: 106): the world designed by a legitimate discourse is not only expressed, but authorised and legitimised. Agents endowed with symbolic capital can exert symbolic power, which is a power of constructing reality. "In the struggle to impose legitimate vision, agents possess power in proportion to their symbolic capital" (Bourdieu, 1991: 106), which is in proportion to the recognition they receive from agents of the field.

Taking a discursive perspective, we can consider regions as social constructs (Allen et al., 1998) that reveal a struggle over the meanings associated with space, borders and regional institutions. In Bourdesian terms, regions "may also be the results of struggle over symbolic capital in different social fields" (Passi, 2001: 13). This relationship between discourse and power is largely recognised in social constructivism in social sciences; more specifically, as for the discourse on European politics, which is the main focus of this article, discursive practices establish power relationships in the sense that they make us "understand certain problems in certain ways, and pose questions accordingly" (Diez, 2001: 90). In studies of discursive approaches to the analysis of European institution building, more oriented by the Habermasian theory of communicative action (Habermas, 1981), European institutions are discourses rather than bargaining arenas (Risse, 2009). This shift from Foucauldian to Bourdesian and Habermasian informed points of view on discourse implies that actors have at least the possibility of acting strategically by shaping their position in relation to a given discursive structure and by attempting to modify the discursive structure itself (Weaver, 2009: 165). Indeed, as Passi (2001: 14) suggests "the language of regionalism (and its capacity to fetishize space and territory) has always been an important strategy for nationalists and regionalists in constructing spatial oppositions, and it is the key medium when the spatialities of power are hidden in rhetoric". From this perspective, discursive strategies can both preserve power, or function as tools to resist to hegemonic processes (De Cillia et al., 1999); therefore, forms of resistance may emerge in the persistence of local idiosyncratic discourses that are embedded and partially segregated from hegemonic national or supra-national discourses.

\section{The fragmentation of European political discourse}

As regions can be conceived as social constructs constituted through discourses, to analyse discourses regarding cohesion policies, we shall focus on two relevant issues, which are where and how relevant political discourses are produced.

The first issue concerns the locus where discourses are produced. A public sphere is a mechanism that links politics to citizens. It is an arena in which political issues and positions are discussed and citizens are mobilised (Adam, 2007, 2009). The European Public Sphere is a concept describing a situation where the same issues are debated in different European national contexts with reference to similar meaning structures (Risse, 2009; Kanter, 2015; Wodak and Krzyżanowski, 2017). Several authors focused on how an European Public Sphere can emerge (Koopmans and Erbe, 2004), and described the positions of the different streams of research regarding this issue (De Vreese, 2007), but scholars agree on the actual lack of a 
real European Public Sphere, with debates fragmented at national level (Risse, 2003; 2009, Triga, and Vadratsikas, 2018).

A second issue is how discourses are produced. In mass democracies, mass media are the most important mechanism to maintain public sphere alive (Adam, 2009). Scholars of politics of the European Union suggest that, by selecting and emphasising issues, actors and frames, mass media actively construct reality (Trenz, 2008: 303). Mass media, however, are likely to produce discourses segregated at national level due to the absence of a common language (Grimm 1995: 294), and this does not contribute to the building of a European public sphere. As Adam notes, media such as Financial Times, The Economist, Le Monde Diplomatique, and TV programs like ARTE and Euronews are read and viewed across European border, but they remain dedicated to elite audiences (2009: 10). Moreover, EU policies generally "lack salience in the minds of European voters" (Moravcsik, 2002: 615), therefore national and regional media are likely to cover EU-related issues only if filtered by, and connected to, local issues and local discourses. A consequence is that for analysing cohesion policy related discourses, which help constructing meaning regarding and around regions, we must focus on national public spheres.

\section{Research context: cohesion policies}

Cohesion policies are designed to reduce economic disparities between European regions in terms of economic development. More specifically, EU uses specifically allocated funds that are labelled structural funds: the European Regional Development Fund (ERDF), the European Social Fund (ESF) and the Cohesion Fund ${ }^{2}$. Three are the aims of cohesion policies (Lelieveldt and Princen, 2011: 186-187): first, structural funds are allocated to economically weaker European regions in order to reduce disparities among regions. Second, funds are allocated to regions that do not fall under the convergence objective in order to strengthen their competitiveness. Finally, funds are allocated to European regions in order to facilitate their territorial cooperation (e.g., funds may be allocated for projects such as the building of a bridge, or a road, that connects border regions in different member states).

Cohesion policies are particularly adequate for investigating power dynamics among different layers of policymaking. Despite nations play a key role when funds are allocated to regions within the EU Council, implementation of policies is delegated to regions and local managing authorities. Indeed, the implementation of cohesion policies is oriented by the 'partnership principle', according to which the "planning, decision-making and implementation of cohesion policy must be made in close consultation with subnational authorities" (Yesilkagit and Blom-Hansen, 2007: 503).

It was the analysis of such fragmented policy-making process that gave rise to the multigovernance perspective to the analysis of EU politics. According to this perspective, EU is a "one-of-a-kind" political system (Lelieveldt and Princen, 2011: 41) characterised by decisionmaking authority dispersed over several level of governance (supranational, national and regional) and in which national governments are no longer the dominant players in EU policymaking. European institutions, subnational authorities and states participate in making

\footnotetext{
${ }^{2}$ Cohesion Fund applies to EU Member States which have a GDP lower than $90 \%$ of the EU-27 average, Croatia not taken into account.
} 
decisions, and "the three parties are in a relationship of mutual dependency rather than hierarchy" (Hooge and Marks, 2001: 86). On similar lines, Yesilkagit and Blom-Hansen (2007) suggest that the allocation of power in cohesion studies calls for the analysis of the entire network of implementation. As the two authors suggest (Yesilkagit and Blom-Hansen, 2007: 504):

EU cohesion policy operates in areas where the member states have had their own national cohesion policies - national labour market policies and regional development policies - for much longer than the EU cohesion policy has been in existence.

Therefore, we expect that the implementation of cohesion policies provides a well suited context to analyse how regions emerge as battle fields of meanings, in which pre-existing national policies compete with European cohesion policies and the principle of partnership between states and regions is a contested issue. As Hooge (1996) suggests, the partnership principle created the ground on which the hegemony of national executives is challenged by subnational authorities.

\section{Method and data}

As we aimed at studying the relationship between cohesion policy implementation and media discourse around cohesion policy, we collected both textual data to elicit meanings, and absorption rates to distinguish between different regions. In particular, being cohesion policy organised in programs of seven years, we focused on the period 2007-2013.

In order to analyse media debate around cohesion policy, we focused on newspapers' articles. The study of language permits to investigate phenomena otherwise hard to analyse (Rhodes and Brown, 2005). Words, in general, have the power to shape thoughts and action (Czarniawska, 1997; Hardy et al., 2000, Hendry, 2000, Phillips et al., 2004). Vocabularies constitute discourses (Loewenstein et al., 2012, Ocasio \& Joseph, 2005), that have the performative power of constructing reality (Bourdieu, 1991). Newspapers' articles, in particular, are a worthy source of data, as they provide information regarding what elite are doing, as newspapers covers issues when legitimised institutional actors pay attention to them, or when political actors are proposing debate or legislative decree (Janssen et al., 2008; Molotch and Lester, 1974; Reese, 1991). Moreover, journalists usually build stories around quotes or direct paraphrase of legitimate actors, leveraging assumptions and narratives that "those authorized speakers use to frame the topic at hand" (Di Maggio et al., 2013: 573). Finally, newspapers' articles influence the ideas of the audience (Di Maggio et al., 2013).

In order to reconstruct meanings molded in the public debate (Meyer and Hoellerer, 2010) we relied on Topic Modelling (TM), which is a technique to automatically extract meanings from a corpus of texts (Blei et al., 2003). Topic modelling codes words within texts into a set of 'topics', that are containers of meaningful words (Mohr and Bogdanov, 2013): “topic modeling provides a valuable method for identifying the linguistic context that surrounds social institutions" (Di Maggio et. al, 2013: 570). In particular, Topic Modelling was recently used to analyse the communication of Cohesion Policy on social media (Barberio et al., 2020)

Topics are set of words that co-occur together or co-occur in similar ways. Topic modelling has several good features: the first one is that data, that are topics, are explicit and other 
researchers may reproduce the analysis. Second, meaning extraction is automated, and thus topic modelling can analyse large corpora of texts impossible to deal with for a human being. Third, inductive nature of the research is preserved, and topics permit to discover unexpected results, as they do not need the imposition of a priori categories. Induction is postponed to topic interpretation, where researchers must dig deep into data and use their knowledge of the field in order to make sense of results. Fourth, topic modelling recognises the relationality of meanings, as it treats terms as varying in meaning across different contexts and recognises that the meaning of a word depends on the surrounding words (DiMaggio et al., 2013). Topic Modelling is gaining legitimation in management studies (Hannigan et al., 2019), and was already widely used in sociological studies dealing with meanings. In example, it was used to make sense of societal issues (Miller, 2013), to analyse media attention for terrorist alert (Bonilla and Grimmer, 2013), and to analyse the 'grammar of motives' in National Security Strategies (Mohr et al., 2013).

There are several algorithms to perform TM: the most diffused one requires no a priori impositions and is thus the most inductive, as it develops topics without any supervision. This algorithm is called Latent Dirilecht Allocation (LDA, Blei et al., 2003), and is based on Bayesian statistics. There are, however, two decisions that the researcher should take before running the model. The first one regards the number of topics that the model should produce. The second concerns whether topics should contain an equal number of words or not. The main output of the algorithm consists of (i) a set of topics, each one described by a list of the most important words that constitute it; (ii) statistics regarding how each article in the sample is composed by the different topics; and (iii) the description of how each word in the corpus was coded.

Our data consists of a collection of 414 newspapers' articles from 2007 to 2015, that we extracted from La Repubblica, which is the second most important Italian journal. We selected this outlet, as it has a national edition, together with several regional editions. This feature permitted us to analyse variations in national/local discourses. Also, while we focus on the programming period 2007-2013, we sampled articles for two more years to be sure to capture also the 'tail' of the media discourse, as it just does not end at the end of the programming period. In order to avoid collecting articles that did not deal with Regional and Cohesion Policies, we selected all the articles containing exactly the words 'European Union' ${ }^{3}$ and one among the following expressions:

- 'Cohesion Policies' ('politiche di coesione');

- 'Regional Policies' ('politiche regionali');

- 'Structural Funds' ('fondi strutturali');

- 'Nuts' (Nomenclature of Territorial Units for Statistics);

- 'European Social Fund' ('fondo sociale europeo');

- 'European Regional Developmente Fund' ('fondo europeo di sviluppo regionale').

We ended up conducting the textual search asking for the exact matching of the sentence, as without double quotes the number of articles not really dealing with Regional and Cohesion Policies was far too high. As our aim is analysing the specificities of the national and regional discourses, we collected both articles from the national edition of the newspaper and from the regional editions. In particular, we collected articles from all the nine regional editions:

\footnotetext{
${ }^{3}$ Indeed, we searched for 'Unione Europea', as the articles were written in Italian and referring to this country. In this article, though, we will try to present both the Italian words and the English translation.
} 
Campania, Puglia, Sicilia, Emilia Romagna, Lazio, Liguria, Lombardia, Piemonte, Toscana. and the nine regions included differ along two dimensions: first, sampled regions are characterised by different structural/historical traits. We focused on the different economic development of Italian regions, as this issue is relevant for Cohesion Policy, Indeed, in relation to their different economic development, European regions are differently classified in terms of the objectives of the European cohesion policies. As for the 2007-2013 programming period, Calabria, Campania, Puglia e Sicilia were classified under the 'Convergence' objective and Emilia Romagna, Piemonte, Lombardia, Lazio, Liguria, and Toscana were included into the 'Competition' objective. 'Convergence' objective includes regions that have a per capita GDP of less than $75 \%$ of the EU-27 average and are considered as less developed in terms of economic growth. Allocation of structural funds are aimed at supporting the catch up by these less developed regions in order to promote the economic convergence among European regions. The 'Convergence' objective is financed by the ERDF and the ESF as well as the Cohesion Fund. The regional 'competitiveness' and employment objective covers all the areas of the European Union not eligible for the convergence objective. It aims to reinforce the regions' competitiveness and attractiveness as well as employment, by anticipating economic and social changes, and it is as well funded by the ERDF and the ESF. To perform the TM we used Mallet (McCallum, 2002), an open-source software developed by University of Massachusetts Amherst. Before analysing data we developed a stop-word list, which is the list of the word that the software has to ignore. This list usually includes articles, prepositions, adverbs and words, which meaning does not add anything to a topic. Actual number of words analysed, words in stop-word list excluded, is 149.475

Topics are ontologically different, if compared to each other, and the researcher must analyse them, going back and forth from the list of words to the original data, in order to grasp the meaning of each set of words. Topics can be themes, discourse, or "[...] may be viewed as frames (semantic contexts that prime particular associations or interpretations of a phenomenon in a reader) and employed accordingly"(DiMaggio et al., 2013: 578). Some other topics are simply residual, as they collect words that fill up wider discourse. Discourses and frames shares the 'performative magic' of being able to construct reality (Bourdieu, 1991:106). Indeed, discourse has a performative power (Phillips et al., 2004) as it "[...] 'rules in' certain ways of talking about a topic, defining an acceptable and intelligible way to talk, write and conduct oneself, and also 'rules out', limits and restricts other ways of talking, of conducting ourselves in relation to the topic or constructing knowledge about it" (Hall, 2001: 71). Discourses, thus, "[...] do not just describe things, they do things" (Potter and Wetherell, 1987: 6). This is the dimension of discourse that "[...] shapes the nature of the discursive practice and the constitutive/constructive effects of discourse" (Fairclough, 1992: 4). On the other hand, frames, that are "knowledge structure that can help individual to organize and interpret incoming perceptual information" (Cornelissen and Werner, 2014: 187), as they are schemata of interpretation that enable individuals to locate, perceive, identify, and label occurrences within their life space. (Goffman, 1974; Gamson and Modigliani, 1989). Conflicting frames may struggle in discursive spaces (Meyer and Hoellerer, 2010; Hardy and Maguire, 2010), and challenging frames may substitute the dominant ones as institutionalised frames (Lounsbury et al., 2003; Cornelissen and Werner, 2014), of taken for granted schemata of interpretation of reality, thus changing interpretation of reality by agents of the fields. This, in turns, changes reality itself. 
As for the absorption rate, we used it to characterise regions, as we sampled regions that show different contextual conditions in which cohesion policies are managed. More specifically, we selected regions that show different capabilities in managing structural funds. The more evident measure of such architectural capability is the rate of absorption of funds, which is the percentage paid to each Region compared to total available budget. Regions with higher absorption rates are better able to use all the available budget allocated from the EU. For this purpose, we relied on data from Eurispes focusing on the 2007-2013 programming period.

\section{Results}

Our first results regard absorption rates. Table 6.1 presents data regarding funds allocation and utilisation in Italian convergence regions programming period 2007-2013 for three regions that we selected, as La Repubblica has a local edition. These regions are Campania, Puglia, and Sicilia. We present data regarding both European Social Fund (ESF), and European Regional Development Fund (ERDF). Table 6.2 presents the percentage utilisation of these funds in the abovementioned regions. Table 6.3 and Table 6.4 presents similar data for six competition regions that we selected, as in these regions we have a local edition of La Repubblica. The regions selected are Emilia Romagna, Lazio, Liguria, Lombardia, Piemonte, and Toscana

\begin{tabular}{|l|c|c|c|c|c|c|}
\cline { 2 - 7 } \multicolumn{1}{c|}{} & \multicolumn{2}{c|}{ ERDF } & \multicolumn{2}{c|}{ ESF } & \multicolumn{2}{c|}{ TOTAL } \\
\hline Region & $\begin{array}{c}\text { Funds } \\
\text { allocated }\end{array}$ & $\begin{array}{c}\text { Funds not } \\
\text { utilised }\end{array}$ & $\begin{array}{c}\text { Funds } \\
\text { allocated }\end{array}$ & $\begin{array}{c}\text { Funds not } \\
\text { utilised }\end{array}$ & $\begin{array}{c}\text { Funds } \\
\text { allocated }\end{array}$ & $\begin{array}{c}\text { Funds not } \\
\text { utilised }\end{array}$ \\
\hline Campania & $3,432.40$ & $2,289.41$ & 559.0 & 228.63 & $3,991.40$ & $2,518.04$ \\
\hline Puglia & $2,619.02$ & $1,063.32$ & 639.6 & 243.05 & $3,258.62$ & $1,306.37$ \\
\hline Sicilia & $3,269.80$ & $1,945.53$ & $1,042.15$ & 454.38 & $4,311.95$ & $2,399.91$ \\
\hline
\end{tabular}

Table 6.1. Funds allocation and utilisation in Italian convergence regions programming period 20072013 (Mil €) [Source: Eurispes].

\begin{tabular}{|l|c|c|c|}
\hline Region & ERDF & ESF & TOTAL \\
\hline Campania & $33 \%$ & $59 \%$ & $\mathbf{3 7} \%$ \\
\hline Puglia & $59 \%$ & $62 \%$ & $\mathbf{6 0} \%$ \\
\hline Sicilia & $41 \%$ & $56 \%$ & $\mathbf{4 4} \%$ \\
\hline
\end{tabular}

Table 6.2. Percentage utilisation in Italian convergence regions programming period 2007-2013 (\%) [Source: our elaboration on data from Eurispes].

\begin{tabular}{|l|c|c|c|c|c|c|}
\cline { 2 - 7 } \multicolumn{1}{c|}{} & \multicolumn{2}{c|}{ ERDF } & \multicolumn{2}{c|}{ ESF } & \multicolumn{2}{c|}{ TOTAL } \\
\hline Region & $\begin{array}{c}\text { Funds } \\
\text { allocated }\end{array}$ & $\begin{array}{c}\text { Funds not } \\
\text { utilised }\end{array}$ & $\begin{array}{c}\text { Funds } \\
\text { allocated }\end{array}$ & $\begin{array}{c}\text { Funds not } \\
\text { utilised }\end{array}$ & $\begin{array}{c}\text { Funds } \\
\text { allocated }\end{array}$ & $\begin{array}{c}\text { Funds not } \\
\text { utilised }\end{array}$ \\
\hline Emilia Romagna & 142.73 & 39.11 & 313.50 & 93.11 & 456.23 & 132.22 \\
\hline Lazio & 368.47 & 142.97 & 365.25 & 131.49 & 733.72 & 274.46 \\
\hline
\end{tabular}




\begin{tabular}{|l|c|c|c|c|c|c|}
\cline { 2 - 7 } \multicolumn{1}{c|}{} & \multicolumn{2}{c|}{ ERDF } & \multicolumn{2}{c|}{ ESF } & \multicolumn{2}{c|}{ TOTAL } \\
\hline Region & $\begin{array}{c}\text { Funds } \\
\text { allocated }\end{array}$ & $\begin{array}{c}\text { Funds not } \\
\text { utilised }\end{array}$ & $\begin{array}{c}\text { Funds } \\
\text { allocated }\end{array}$ & $\begin{array}{c}\text { Funds not } \\
\text { utilised }\end{array}$ & $\begin{array}{c}\text { Funds } \\
\text { allocated }\end{array}$ & $\begin{array}{c}\text { Funds not } \\
\text { utilised }\end{array}$ \\
\hline Liguria & 166.76 & 55.36 & 146.34 & 103.31 & 313.1 & 158.67 \\
\hline Lombardia & 210.74 & 66.59 & 337.25 & 115 & 547.99 & 181.59 \\
\hline Piemonte & 422.87 & 141.66 & 394.62 & 109.7 & 817.49 & 251.36 \\
\hline Toscana & 338.47 & 124.89 & 310.65 & 86.05 & 649.12 & 210.94 \\
\hline
\end{tabular}

Table 6.3. Funds allocation and utilisation in Italian competition regions programming period 20072013 (Mil €) [Source: Eurispes].

\begin{tabular}{|l|c|c|c|}
\hline Region & ERDF & ESF & TOTAL \\
\hline Emilia Romagna & $73 \%$ & $70 \%$ & $\mathbf{7 1} \%$ \\
\hline Lazio & $61 \%$ & $64 \%$ & $\mathbf{6 3} \%$ \\
\hline Liguria & $67 \%$ & $29 \%$ & $49 \%$ \\
\hline Lombardia & $68 \%$ & $66 \%$ & $\mathbf{6 7} \%$ \\
\hline Piemonte & $67 \%$ & $72 \%$ & $\mathbf{6 9} \%$ \\
\hline Toscana & $63 \%$ & $72 \%$ & $\mathbf{6 8} \%$ \\
\hline
\end{tabular}

Table 6.4. Percentage utilisation in Italian competition regions programming period 2007-2013 (\%) [Source: our elaboration on data from Eurispes].

As for the results of textual analysis, in order to grasp meaning from the articles constituting our sample, we performed several cycles of the process that starts by eliciting topics and ends by analysing them in order to select the solution that best describe our object of analysis (Di Maggio et al., 2013). After several attempts, we finally opted for a solution composed of 15 topics containing the same number of words. ${ }^{4}$

Appendix A presents a list of the 40 most important words for each of the 15 topics (topic ID from 0 to 25), both in Italian and in English. The first word in each column is the more most important one to grasp the meaning of the topic. One word can appear in different columns, as the same word can have different meanings in different contexts: the algorithm is able to discriminate the difference in meaning (polysemy). The following Table 6.5 presents and inductively developed label for each of the fifteen topics, together with a short description. To understand the meaning of each topic, we analysed the most important words both alone and in their context. We mean that beyond analysing the lists of words, for each topic we read the articles that were mostly coded at that topic. We went back and forth from the results of Topic Modelling to the original articles until our tentative description of each topic became more

\footnotetext{
${ }^{4}$ Topics can be composed by the same or a different number of words. Generally speaking, if one allows the existence of topics containing a different number of words, he will end up with few very 'big' topics, that capture the more relevant issue in the debate, and several smaller topics that deal with the nuances. Forcing the existence of topics of the same dimensions breaks the main issue of the debate in its constituting themes. In order to choose, one must try several solutions and select the most informative one.
} 
refined, and until authors reach an agreement on the meaning of each topic. It is worth noting that topic order has no relevance.

\begin{tabular}{|c|c|c|}
\hline Topic & Label & Meaning \\
\hline 0 & \begin{tabular}{|l|} 
National \\
Institutions and \\
European Funds
\end{tabular} & $\begin{array}{l}\text { Is composed by words that deal with national institutions, such as } \\
\text { government, president, minister, premier and by words that refer to } \\
\text { European budget and European funds. }\end{array}$ \\
\hline 1 & $\begin{array}{l}\text { Frauds \& } \\
\text { Corruption }\end{array}$ & $\begin{array}{l}\text { This topic is used for articles that deal with misuse and illegal use of } \\
\text { Regional and Cohesion Policies' funds. We have words such as court, } \\
\text { controls, damage, frauds, corruption, prosecutor. Moreover, we have } \\
\text { words that deal with the specific cases where funds where misused. In } \\
\text { example, the word 'education', as several articles constituted by this } \\
\text { topic deal with an organisation who was supposed to give classes to } \\
\text { unemployed students, and thus received money from the EU. Yet the } \\
\text { classes were a fake. }\end{array}$ \\
\hline 2 & \begin{tabular}{|l} 
Jobs \& \\
Development
\end{tabular} & $\begin{array}{l}\text { Is used for dealing with development and the creation of jobs through } \\
\text { European funds. We have words as jobs, government, growth, reforms, } \\
\text { resources. }\end{array}$ \\
\hline 3 & Local institutions & $\begin{array}{l}\text { This topic especially refers to cities and districts (province) and on the } \\
\text { effects of European Funds on these local institutions. We have words } \\
\text { as cities, districts, projects, municipality }\end{array}$ \\
\hline 4 & $\begin{array}{l}\text { Regional policies of } \\
\text { southern regions }\end{array}$ & $\begin{array}{l}\text { This topic is similar to topic } 3 \text {, as it is used to convey an emphasis on } \\
\text { local institutions. Yet, in this case, the focus is on institutions from } \\
\text { Southern Italy: in particular, here we have names of the governors of } \\
\text { Puglia and Campania, two very important regions from southern Italy. } \\
\text { The names are Emiliano and Caldoro. Then we have the same words } \\
\text { Campania and Puglia, together with South and Mezzogiorno, and } \\
\text { Italian expression for south. }\end{array}$ \\
\hline 5 & $\begin{array}{l}\text { Budget of } \\
\text { European } \\
\text { Institutions }\end{array}$ & $\begin{array}{l}\text { The words in this topic are used to refer to the budget of European } \\
\text { Institution, and, in particular, the Commission, that is the second most } \\
\text { important word of this topic. Then we have names of European } \\
\text { Politicians: Juncker, Barroso. Indeed, when dealing with budget, this } \\
\text { topic provides the words for describing the bargaining process } \\
\text { between European Institutions and Italian Government }\end{array}$ \\
\hline 6 & Education & $\begin{array}{l}\text { This topic refers to the use of European Funds to provide better } \\
\text { education for young unemployed. We have words such as young, job, } \\
\text { school, skills, problems, results. }\end{array}$ \\
\hline 7 & Music Festival & $\begin{array}{l}\text { Topic } 7 \text { deals with several musical festivals, that were organised in } \\
\text { Bari, in the region Puglia, thanks to European Funds. Thus, we have } \\
\text { several words related to music, programs and tickets }\end{array}$ \\
\hline 8 & European Funds & $\begin{array}{l}\text { This topic is especially focused on European Funds. We have the words } \\
\text { funds, million, euros, region, trillion, projects, development, social, } \\
\text { commission. This topic, that is the bigger one, contains most of the } \\
\text { technical jargon related to European funds. }\end{array}$ \\
\hline
\end{tabular}




\begin{tabular}{|c|c|c|}
\hline Topic & Label & Meaning \\
\hline 9 & Theatrical Festivals & $\begin{array}{l}\text { This topic contains words that refer to theatrical festival organised, } \\
\text { mainly in northern Italy, thanks to European Funds. We thus have } \\
\text { words such as tickets, ticket office, subscription, festival, prose. }\end{array}$ \\
\hline 10 & Theatrical Classes & $\begin{array}{l}\text { This topic contains words that refer to theatrical classes for children } \\
\text { organised thanks to European Funds. We have words such as classes, } \\
\text { children, kids, courses, age. }\end{array}$ \\
\hline 11 & Emergency & $\begin{array}{l}\text { Topic } 11 \text { contains all the words that refers to the use of European funds } \\
\text { for emergencies such as earthquakes, problematic disposal of rubbish, } \\
\text { natural calamities. We have indeed words as rubbish, emergency, civil } \\
\text { protection, municipality, district, city, solidarity, reconstruction, and } \\
\text { earthquake. }\end{array}$ \\
\hline 12 & $\begin{array}{l}\text { Cohesion policies } \\
\text { for } \\
\text { entrepreneurship }\end{array}$ & $\begin{array}{l}\text { In this topic we find words that refer to research and development to } \\
\text { foster entrepreneurship, thank to European funds. We have words as } \\
\text { enterprises, research, development, innovation, investments, firms, } \\
\text { infrastructures, economy. }\end{array}$ \\
\hline 13 & Macroeconomics & $\begin{array}{l}\text { Topics } 13 \text { is used in articles, that are mainly opinion articles, which } \\
\text { explore the relationship between European Fund and Macroeconomic } \\
\text { European Policy. We thus have the names of some States: Greece and } \\
\text { Germany. Then we have names of politicians: Merkel, Hollande. Then } \\
\text { we have words as growth, reforms, banks, market, unemployment, } \\
\text { recession. }\end{array}$ \\
\hline 14 & $\begin{array}{l}\text { Invitations to } \\
\text { tender }\end{array}$ & $\begin{array}{l}\text { This topic is mostly used for creating articles that deal with invitation } \\
\text { to tender for processes or projects funded by EU. Most of these projects } \\
\text { deals with cultural and creative industries: we have words as tender, } \\
\text { projects, Pompei, cultural. }\end{array}$ \\
\hline
\end{tabular}

Table 6.5. Topics' labels and description.

A general and expected result (Di Maggio et al., 2013) is that topics are ontologically different: some of them are used for wider discourses, whereas other topics just refer to smaller themes. Due to space reasons, it is not possible to analyse in detail all the topics: while in the next section we will focus on the topics that are more relevant for our research question, here we provide some descriptive data regarding all the elicited topics.

Table 6.6 presents data regarding how topics are used in our corpus. The first two columns are topic number and label. For each topic, then, the third column highlights how many times that topic constituted more than $50 \%$ of an article (out of the 414 articles in our dataset). The fourth column has the same information, but in percentage. The fifth column highlights how many times each topic was the most important one in constituting an article, and the sixth column reports the same information, in percentage. Finally, the seventh column portraits the average usage of each topic in our dataset. As we have 15 topics, if topics constituted articles equally, each topic would have an average use of $6.7 \%$ and would be the most important topic for an article about the $6.7 \%$ of times ${ }^{5}$. As actual data differ from casual ones, we can draw

\footnotetext{
${ }^{5}$ As $100 / 15=6.7 \%$.
} 
some conclusions. In example, we labelled Topic 14 as 'invitation to tender': this topic has an average use of $4.1 \%$, which is below the average. This is thus a small topic. Moreover, this topic is the most important for $2.7 \%$ of the articles only, and constitutes more than $50 \%$ of an article only 16 times, out of 414 articles (2.7\%). Following literature on Topic Modelling (Ferri et al., 2018), we can assume that this topic is not characterising articles, as it rarely provides the main meaning to an article. Yet, it is used several times, when an invitation to tender is cited in an article $^{6}$.

\begin{tabular}{|l|l|c|c|c|c|c|}
\hline \multirow{2}{*}{ Topic } & \multirow{2}{*}{ Label } & \multicolumn{2}{|c|}{ Times more 50\% } & \multicolumn{2}{c|}{$\begin{array}{c}\text { Timest important } \\
\text { topic }\end{array}$} & $\begin{array}{c}\text { average } \\
\text { use }\end{array}$ \\
\cline { 3 - 6 } & & number & $\%$ & number & $\%$ & \\
\hline 0 & $\begin{array}{l}\text { National Institutions and } \\
\text { European Funds }\end{array}$ & 5 & $1.2 \%$ & 16 & $3.9 \%$ & $6.6 \%$ \\
\hline 1 & Frauds \& Corruption & 14 & $3.4 \%$ & 25 & $6.0 \%$ & $5.9 \%$ \\
\hline 2 & Jobs \& development & 7 & $1.7 \%$ & 28 & $6.8 \%$ & $7.4 \%$ \\
\hline 3 & Local institutions & 13 & $3.1 \%$ & 18 & $4.3 \%$ & $5.2 \%$ \\
\hline 4 & $\begin{array}{l}\text { Regional policies of southern } \\
\text { regions }\end{array}$ & 18 & $4.3 \%$ & 36 & $8.7 \%$ & $7.0 \%$ \\
\hline 5 & $\begin{array}{l}\text { Budget of European } \\
\text { Institutions }\end{array}$ & 11 & $2.7 \%$ & 28 & $6.8 \%$ & $6.7 \%$ \\
\hline 6 & Education & 12 & $2.9 \%$ & 13 & $3.1 \%$ & $5.2 \%$ \\
\hline 7 & Music Festival & 12 & $2.9 \%$ & 7 & $1.7 \%$ & $2.5 \%$ \\
\hline 8 & European Funds & 26 & $6.3 \%$ & 84 & $20.3 \%$ & $16.6 \%$ \\
\hline 9 & Theatrical Festivals & 42 & $10.1 \%$ & 40 & $9.7 \%$ & $8.5 \%$ \\
\hline 10 & Theatrical Classes & 33 & $8.0 \%$ & 23 & $5.6 \%$ & $6.5 \%$ \\
\hline 11 & Emergency & 16 & $3.9 \%$ & 21 & $5.1 \%$ & $3.7 \%$ \\
\hline 12 & $\begin{array}{l}\text { Cohesion policies for } \\
\text { entrepreneurship }\end{array}$ & 25 & $6.0 \%$ & 41 & $9.9 \%$ & $8.7 \%$ \\
\hline 13 & Macroeconomics & 19 & $4.6 \%$ & 23 & $5.6 \%$ & $5.0 \%$ \\
\hline 14 & Invitations to tender & 16 & $3.9 \%$ & 11 & $2.7 \%$ & $4.1 \%$ \\
\hline
\end{tabular}

Table 6.6. Topics and prevalence.

From Table 6.6 we can draw some conclusion regard topics:

- Topic 0, National Institutions and European Funds, is a gregarious topic, as it has an average use of $6.6 \%$, but is the most important topic only $3.9 \%$ of times

\footnotetext{
${ }^{6}$ We said that topics have the same dimension. Now we add that some of them are used more than others. These two facts are not at odds: dimension refer to the number of words, usage to the actual use of those words. So, two topics may have the same number of words, but the words pertaining to a topic may be used more.
} 
- Topic 1, Frauds \& Corruption, has a balanced use, and is a bit smaller than the expected average

- Topic 2, Jobs \& development, has an average use above the expected average. It characterises several articles, but it is used even when it is not the most important topic

- Topic 3, Local institutions, is small (5.2\% average use) and dispersed (only $4.3 \%$ as more important)

- $\quad$ Topic 4, Regional policies of southern regions, is bigger than average (7\% of average use) and concentrated in few articles, as it is the most important topic $8.7 \%$ of times. This means that in articles when this topic is not the most important one, it is not used a lot.

- $\quad$ Topic 5, Budget of European Institutions, has both an average use (6.7\%), and the use as most important topic $(6.8 \%)$ on average.

- Topic 6, Education, is small and rarely and dispersed, as rarely is the most important topic $(3.1 \%)$

- $\quad$ Topic 7, Music Festival, is the smaller one (2.5\% average use) and very disperse (only $1.7 \%$ times as most important)

- Topic 8, European Funds, is the biggest topic, as it constitutes on average $16.6 \%$ of the articles in our dataset. Moreover, it is the most important topic for $20.3 \%$ of articles.

- $\quad$ Topic 9, Theatrical Festivals, is big (8.5\% mean use) and concentrated (9.7\% of times most important topic)

- Topic 10, Theatrical Classes, has a medium dimension (6.5\%) but is more dispersed (5.6\% times first)

- Topic 11, Emergency, is small, as it accounts for only 3.7\% of the dataset. Yet, it is very important in the articles that deal with emergency, as it is the most important topic for $5.1 \%$ articles.

- Topic 12, Cohesion policies for entrepreneurship, is big (8.7\%) and important for a relevant number of articles $(9.9 \%)$

- Topic 13, Macroeconomics, has a use a bit below average $(5.0 \%)$ and is the most important $5.6 \%$ of times.

- Topic 14, Invitations to tender, as we saw, is small and dispersed.

Table 6.7 describes the different usage of topics for the different sections of the newspaper. There are no topics, which use is balanced between national and regional sections: we only have topics that are prevalent in national section (i.e., Topic 2, Topic 5, Topic 6, Topic 9, Topic 10, Topic 12, and Topic 13), and topics that are prevalent in local sections (i.e., Topic 0 , Topic 1, Topic 3, Topic 4, Topic 7 , Topic 8 , Topic 11, and Topic 14). In some cases, the disequilibrium is quite impressive: Topic 9, in example, constitutes $9.2 \%$ of articles in national sections, whereas it constitutes only $0.2 \%$ of articles in regional sections. Topic 1 , on the contrary, which is about fraud and corruption, has an average use in regional sections that is more than double than the one in national sections. These data permit us to draw conclusions on the different themes that are treated in national of local debate, as we will do in the next section. 


\begin{tabular}{|l|l|c|c|}
\hline \multirow{2}{*}{ topic } & \multicolumn{2}{c|}{ use on sections } \\
\cline { 3 - 4 } & & national & regional \\
\hline 0 & National Institutions and European Funds & $6.2 \%$ & $10.0 \%$ \\
\hline 1 & Frauds \& Corruption & $5.1 \%$ & $12.5 \%$ \\
\hline 2 & Jobs \& development & $7.6 \%$ & $6.4 \%$ \\
\hline 3 & Local institutions & $5.1 \%$ & $6.6 \%$ \\
\hline 4 & Regional policies of southern regions & $6.7 \%$ & $9.9 \%$ \\
\hline 5 & Budget of European Institutions & $7.0 \%$ & $4.5 \%$ \\
\hline 6 & Education & $5.3 \%$ & $4.5 \%$ \\
\hline 7 & Music Festival & $2.3 \%$ & $4.6 \%$ \\
\hline 8 & European Funds & $16.1 \%$ & $21.2 \%$ \\
\hline 9 & Theatrical Festivals & $9.4 \%$ & $0.2 \%$ \\
\hline 10 & Theatrical Classes & $7.2 \%$ & $0.3 \%$ \\
\hline 11 & Emergency & $3.6 \%$ & $4.5 \%$ \\
\hline 12 & Cohesion policies for entrepreneurship & $9.0 \%$ & $6.3 \%$ \\
\hline 13 & Macroeconomics & $5.4 \%$ & $1.9 \%$ \\
\hline 14 & Invitations to tender & $3.8 \%$ & $6.6 \%$ \\
\hline
\end{tabular}

Table 6.7. Usage of topics in national and regional section.

Table 6.8, finally, tackles how different regional editions of La Repubblica are constituted differently by topics. In particular, differences between convergence and competition regions are highlighted. In example, articles from the regional section of Bologna that deal with European Regional and Cohesion Policies, deals especially with European Funds in general (Topic $8,21.4 \%$ ). The second topic is the number 11 , emergency, with $17.3 \%$. This result make sense, as in 2012 the region was hit by a severe earthquake. Then we have jobs and development (Topic 2, 12.1\%), cohesion policies for entrepreneurship and Local institutions. These data permit us to disentangle the local public debate in its component, as we will do in the next section. 
punt-Oorg

\begin{tabular}{|c|c|c|c|c|c|c|c|c|c|c|}
\hline \multirow{3}{*}{\multicolumn{2}{|c|}{ topic }} & \multicolumn{9}{|c|}{ regional sections } \\
\hline & & \multicolumn{3}{|c|}{ convergence regions } & \multicolumn{6}{|c|}{ competition regions } \\
\hline & & $\begin{array}{c}\text { Napoli } \\
\text { Campania }\end{array}$ & Bari Puglia & $\begin{array}{l}\text { Palermo } \\
\text { Sicilia }\end{array}$ & $\begin{array}{c}\text { Bologna } \\
\text { Emilia } \\
\text { Romagna }\end{array}$ & Roma Lazio & $\begin{array}{l}\text { Genova } \\
\text { Liguria }\end{array}$ & $\begin{array}{c}\text { Milano } \\
\text { Lombardia }\end{array}$ & $\begin{array}{c}\text { Torino } \\
\text { Piemonte }\end{array}$ & $\begin{array}{l}\text { Firenze } \\
\text { Toscana }\end{array}$ \\
\hline 0 & $\begin{array}{l}\text { National Institutions } \\
\text { and European Funds }\end{array}$ & $9.4 \%$ & $13.4 \%$ & $11.1 \%$ & $7.9 \%$ & $6.1 \%$ & $18.0 \%$ & $0.2 \%$ & $0.2 \%$ & $0.5 \%$ \\
\hline 1 & Frauds \& Corruption & $7.1 \%$ & $3.0 \%$ & $31.9 \%$ & $2.7 \%$ & $8.9 \%$ & $2.8 \%$ & $63.0 \%$ & $0.2 \%$ & $17.5 \%$ \\
\hline 2 & Jobs \& development & $6.1 \%$ & $5.1 \%$ & $5.2 \%$ & $12.1 \%$ & $5.2 \%$ & $17.6 \%$ & $8.3 \%$ & $1.9 \%$ & $3.1 \%$ \\
\hline 3 & Local institutions & $4.1 \%$ & $3.4 \%$ & $10.5 \%$ & $10.1 \%$ & $0.3 \%$ & $4.8 \%$ & $0.2 \%$ & $63.7 \%$ & $1.4 \%$ \\
\hline 4 & $\begin{array}{l}\text { Regional policies of } \\
\text { southern regions }\end{array}$ & $20.2 \%$ & $12.0 \%$ & $2.7 \%$ & $3.9 \%$ & $9.9 \%$ & $2.5 \%$ & $0.2 \%$ & $0.7 \%$ & $0.5 \%$ \\
\hline 5 & $\begin{array}{l}\text { Budget of European } \\
\text { Institutions }\end{array}$ & $7.3 \%$ & $3.5 \%$ & $3.5 \%$ & $3.1 \%$ & $3.4 \%$ & $2.4 \%$ & $0.2 \%$ & $9.2 \%$ & $4.0 \%$ \\
\hline 6 & Education & $4.8 \%$ & $3.9 \%$ & $4.8 \%$ & $7.4 \%$ & $2.2 \%$ & $7.3 \%$ & $1.7 \%$ & $0.2 \%$ & $4.0 \%$ \\
\hline 7 & Music Festival & $0.3 \%$ & $15.3 \%$ & $0.3 \%$ & $1.4 \%$ & $0.3 \%$ & $4.0 \%$ & $1.7 \%$ & $0.2 \%$ & $4.6 \%$ \\
\hline 8 & European Funds & $20.6 \%$ & $24.4 \%$ & $15.7 \%$ & $21.4 \%$ & $32.9 \%$ & $23.2 \%$ & $21.4 \%$ & $12.0 \%$ & $16.4 \%$ \\
\hline 9 & Theatrical Festivals & $0.3 \%$ & $0.1 \%$ & $0.1 \%$ & $0.2 \%$ & $0.3 \%$ & $0.4 \%$ & $0.2 \%$ & $0.2 \%$ & $1.4 \%$ \\
\hline 10 & Theatrical Classes & $0.4 \%$ & $0.3 \%$ & $0.1 \%$ & $0.2 \%$ & $0.1 \%$ & $0.4 \%$ & $0.2 \%$ & $0.2 \%$ & $0.2 \%$ \\
\hline 11 & Emergency & $2.1 \%$ & $4.6 \%$ & $1.7 \%$ & $17.3 \%$ & $9.7 \%$ & $5.0 \%$ & $0.2 \%$ & $0.2 \%$ & $7.4 \%$ \\
\hline 12 & $\begin{array}{l}\text { Cohesion policies for } \\
\text { entrepreneurship }\end{array}$ & $4.5 \%$ & $7.7 \%$ & $4.2 \%$ & $10.4 \%$ & $10.1 \%$ & $6.2 \%$ & $0.2 \%$ & $8.6 \%$ & $8.0 \%$ \\
\hline 13 & Macroeconomics & $0.9 \%$ & $1.9 \%$ & $2.3 \%$ & $1.6 \%$ & $3.8 \%$ & $5.0 \%$ & $0.2 \%$ & $2.4 \%$ & $0.2 \%$ \\
\hline 14 & Invitations to tender & $12.1 \%$ & $1.3 \%$ & $5.7 \%$ & $0.2 \%$ & $6.7 \%$ & $0.4 \%$ & $1.7 \%$ & $0.2 \%$ & $31.0 \%$ \\
\hline
\end{tabular}

Table 6.8. Usage of topics in regional sections.

PIJ/Volume 5 - Issue 2/2020 


\section{Discussion}

A first consideration regards the presence of the debate on structural funds on regional newspapers. It seems that the issue of structural funds and cohesion policies is salient in convergence objective regions, more than in competition regions. In our sample we retrieved articles that are mostly published in local sections of regions that are in the convergence objective. In regions with high GDP per capita, discourse on cohesion policies is virtually absent in the local sections of newspaper (for example, in or sample, we were able to include only one article for Piemonte and Lombardia). A first explanation is the fact that the amount of funds directed to these regions is much lower than the amount of funds for convergence regions (compare Table 6.1 and Table 6.3) and, therefore, the theme of cohesion policies is less salient. Saliency, of course, may temporarily be connected to specific events. For example, in the local edition of Milano (Lombardia) the discourse on cohesion policies is mainly connected to Topic 1 , which addresses the mismanagement of structural funds. The temporary saliency of cohesion policies in local public opinion is connected to a specific case of corruption or fraud in connection of the management of structural funds.

A second consideration concerns at what level - national or regional - the topics are more frequently debated. This consideration leads to the question of why specific topics are differently relevant at national and regional level. Or how the discourse on cohesion policies gets organised along the dimension national-local. As shown in Table 7, within the discourse on cohesion policies, Topic 2, Topic 5, Topic 6 (partially), Topic 12, and Topic 13 are mainly located at national level whereas Topic 0 , Topic 1 , Topic 3, Topic 4, Topic 8 , and Topic 11 coalesce at regional level. As expected, topics that are located at national level are permeated by a macro-economic scope and address themes that are relevant at the national and international levels. For example, they speak to issues such as labour in the context of regional economic policies (Topic 2); financial and budgetary analysis of the relationships between Italy and the EU (Topic 5); the role of cohesion policies within the framework of industrial policies and entrepreneurship (Topic 12); and the role of cohesion policies in the context of the macroeconomic concern for growth and financial debt of EU countries (Topic 13). On the other hand, topics located at regional level take issue with local problems such as waste disposal or recovery from natural disasters (Topic 11), regional policies of southern regions (Topic 4) or problems of local administration (Topic 3 ).

Interestingly, Topic 6, which spans over national and local public opinion, addresses the national issue of using structural funds to support regional educational programmes and the issue of the hierarchical level at which education policies need to be managed. For example, the words 'competenza' and 'livello' recur. In Italian, they respectively refer to the attribution of the subject that bears the responsibility and the authority connected to a specific task or objective, and the hierarchical level at which the authority and responsibility is located. In addition, the word 'crisi' (crisis) and 'problema' or 'problemi' (problem or problems) emphasise a tension that revolves around the issue of subsidiarity, that is, the extent to which authority to implement cohesion policies should be assigned to national and local authorities. This topic reveals the latent tension that is at the centre of the multi-governance perspective to the analysis of EU politics (Hooge and Marks, 2001). The dispersion of authority over several level of governance (supranational, national and regional) (Lelieveldt and Princen, 2011) triggers a conflict of attribution that is a struggle for legitimacy, resources and hegemony. The 
struggle takes place in an extended public sphere that almost equally involve national and regional levels (see Table 6.7 and Table 6.8) and that equally involve sampled regions, independently of geographical location (North/South), economic development (objective convergence/competition) and absorption performances (low performers/high performers) (see Table 6.2 and Table 6.4).

On the other hand, when we analyse the topics that are unambiguously located at regional level, the tension between local and national hierarchical and administrative levels materialises in local discourses that address the issue of cohesion policies, and the connected hegemonic struggle, by recasting the discourse in a local versions that build on specific interpretations of, often problematised, local identities. In such local discourses, a key issue regards how European cohesion policy is reinterpreted in the light of both contingent facts and identity traits of regions. This localised discourse reinforces power relations among regions, and between regions and national administration. To make an example, Topic 3 addresses the relations between national and local administration of cohesion funds. Here, the theme focuses on the role of provinces ('provincia' and 'province'), municipalities ('comune') and chambers of commerce ('camere di commercio'). The role of these local entities is legitimised by referring to a connection between glorious past ('passato') and bright future ('future'). These two dimensions are typical tools of temporalisation to build and consolidate identities. As Passi (2001: 20) suggests, “territorial identity discourses include the temporalisation of the community, that is the narratives and memories of the past, images of the present and often utopias of the future". Here, interestingly, the region that has more voice is Toscana. This region has a relatively good performance in its track-record of absorption rate (Table 6.4) and is a relatively rich region that is not included into the convergence objective. In this context, the role of local authorities in managing cohesion fuds is salient.

On the other hand, regions plagued by corruption and frauds cases, or specific events that interact with structural funds allocation, are forced to address the national-local power discursive struggle from different, often weaker, positions. For example, in Topic 1, the local management of cohesion funds is treated. As mentioned, the topic revolves around the problems related to corruption and frauds. As expected, the topic is particularly salient in regions in which cases of corruption and frauds took place. It is interesting to mention that for a region as Sicilia ${ }^{7}$ the discourse on cohesion policies is attracted by this topic. The emerging of cases of corruption redirected the discourse on national-local management so that this is reshaped into the issue of wasted taxpayers' money and the opportunity to let local authorities managing funds.

Similarly, in Topic 11 the issue of cohesion funds is mentioned in connection with specific emergencies. For example, in Emilia-Romagna the use of European funds is addressed in connection to the earthquake that plagued the regions in 2012. However, Topic 11 again reveals the localisation of discursive struggle: most of the topic is connected to the use that Campania region and Napoli made of European funds to address long-standing problem in waste-disposal. Here, again, the national-local struggle refocuses on the stigmatisation of mismanagement of European structural funds by local administrations. Differently from the case of Sicilia, however, despite the fact that the case of Campania and Napoli's waste-disposal

\footnotetext{
${ }^{7}$ Despite the fact that Lombardia is present in Topic 1 as well as Sicilia, we focus on Sicilia because the data are more reliable. On the other hand, as for Lombardia, the presence in Topic 1 is the consequence of only one article, which happens to report a case of frauds that attacted public attention.
} 
recur in local newspapers articles in many regions, this topic is not salient and particularly present in the local discourse in Campania region itself. Campania, on the contrary, is concentrated mostly on Topic 8, which addresses the national-local struggle in terms of relative redistribution of funds among regions. The topic is mainly located at regional level and focuses on the way in which funds are redistributed among regions and the magnitude of funds allocated to Italian regions. In other words, whereas in other regions mass-media framed discourse on cohesion funds in relation to waste-management inefficiencies in Campania, in this region this topic is not salient in the discourse on cohesion policies. Despite this region is a convergence region (revealing a weak economic development), was not among the most efficient users of structural funds (see Table 6.2) and was plagued by contingent emergencies connected to the use of structural funds, the discourse addressed the national-local struggle in terms of relative redistribution of funds among regions (Topic 8).

What emerges from our analysis is that power struggle does not manifest itself in the discourse in a homogenous way; rather it adapts, or tries to adapt, to idiosyncratic characteristics of specific segments of the public sphere. More specifically we analysed three groups of characteristics: structural/historical, contextual and contingent. Structural/historical elements were operationalised as the level of economic development of each region as captured by the inclusion in either convergence or competition objective. Contextual elements were operationalised as the effectiveness of a specific local managing authority to use allocated structural funds as measured by absorption rate. Finally, we considered contingent elements as those salient events that attract public opinion (cases of corruption or frauds, natural plagues such as the earthquake in Emilia Romagna and the boosting of problems such as waste-disposal systems and waste accumulation in cities such as Napoli and Roma).

We found that the power struggles that involves the national and the local level in the management of the European cohesion policies and structural funds adapts to local public sphere. At the local level, structural/historical, contextual and contingent elements may contribute to strive local discourse and, in doing so, to influence power relations. More precisely, we noted three different processes that are captured by looking at how topics emerge, locate in national/local public sphere and attract attention of local media. First, we found a process of leverage when in a local public sphere discourse leverages structural/historical, contextual or contingent elements. For example, in Toscana, local discourse leveraged its track-record of absorption rate and its position within those regions that receive funds for increasing their competitiveness rather that for catching up. Indeed, in the period analysed, local discourse was manly concentrated on Topic 3 and revolved around the need for greater autonomy.

A second process is one of capture. In this case, public opinion and local discourse is captured by structural/historical, contextual or contingent elements. These elements mould local discourse. In this way, power struggle is reframed into specific local context. This was the case of Sicilia and Topic 1. Here, contingent elements, such as the occurring of episodes of corruption or frauds captured local discourse on cohesion policies. These contingent elements were amplified and blended with by contextual elements (low absorption rated) and historical/structural elements (need for fund to catch up economic development of other 
Italian and European regions). Most of articles combine ineffective public administration ${ }^{8}$ with the cases of corruption and bribery to explain the failure in using European funds and the region's economic backwardness. In this case, the local discourse highlighted the weaknesses of the Sicilia region and reproduced power relations between the national and local levels.

Finally, we identified a process of resistance in the analysis of the Campania region. Here, salient contingent elements (waste-management crisis), historical/structural elements (need for structural funds to achieve convergence) and contextual elements (low absorption rated) all conjured up to capture local discourse on cohesion policies. Intriguingly, the wastemanagement problems emerged in Campania was a salient theme connected to Topic 11 in the local discourse on cohesion policies in other regions, not in Campania. Local discourse on cohesion funds was only marginally attracted by Topic 11. Rather, much of local discourse in Campania was centred on Topic 8 .

\section{Conclusions}

In conclusion, local discourse both reveals and reinforces power relations. Factors connected to the specific context of programming periods - transparency and effectiveness of local authorities in managing local funds - , contingent events taking place in the programming periods (cases of frauds, natural plagues or other salient events) and structural factors pertaining to regions' history of economic and social development - as crystallised by the classification as convergence or competition objectives - affects the way in which cohesion policies are treated in the local media. This, however, involves the reallocation of power between national and local managing authorities in the European multi-level governance of cohesion funds.

While we carefully analysed the Italian case, we must acknowledge that both the implementation and the discourses around Cohesion Policy are largely dependent by the national context, which includes both institutional elements, such as the level of decentralisation of the State, the authorities in charge for implementation and communication of cohesion policy, and the degree of autonomy of such institutions. The local context is particularly relevant for the meaning structures around cohesion policy, to the extent that policymakers must communicate cohesion policy by (Mollona et al., 2019: 15):

[...] appropriately selecting the key messages to be communicated, policy-makers should elicit local "discursive opportunity structures". This endeavour, we advocate, aims at drawing out idiosyncratic, deep-seated, hot, emotional and sensitive topics that emerge locally.

Therefore, our results cannot be simply extended to other countries, as more research is needed to inquiry the meaning structures around cohesion policy in other European countries and regions. To overcome this limitation, further works will enlarge the analysis in three

\footnotetext{
${ }^{8}$ For example, in one of the analysed article it is claimed that organisational units responsible for the management of funding requests by enterprises operating in the area of photovoltaic and wind-power were 'fuori da ogni controllo' (out of control) and no protocol existed to manage the priority order of requests ('Non c'era un protocollo per stabilire l'ordine delle domande').
} 
directions. First, it would be interesting to include more than one journal for each country. Of course, this will bring about the problem of journal selection. A second avenue for exploration is the inclusion of foreign newspapers in the sample, in order to repeat this analysis in several European countries and regions. The aim would be to assess the impact of different institutional arrangements and meaning structures on the local adaptations of the discourse around cohesion policy. Finally, a look at informative documents produced directly by the European commission could be included in the analysis. Such a look at supranational sources of information could be useful to elicit a more complete articulation of the evolution of the discourse on European policies when moving form supranational, national and regional levels.

\section{Keywords}

cohesion policy; topic modelling; discourses; public sphere; local adaptation; Italy

\section{Reference list}

Adam, S. (2007), "Domestic Adaptations of Europe: A Comparative Study of the Debate on EU Enlargement and a Common Constitution in the German and French Quality Press", International Journal of Public Opinion Research, 19 (4): 409-433.

Allen, J., Massey, D., and Cochrane, A. (1998), Rethinking the Region, Routledge: London.

Barberio, V., Kuric, I., Mollona, E., and Pareschi, L. (2020), “The Use of Social Media in EU Policy Communication and Implications for the Emergence of a European Public Sphere", Investigaciones Regionales - Journal of Regional Research, 46 (1): 111-129.

Blei, D.M., Ng, A.Y., and Jordan, M.I. (2003), “Latent Dirichlet Allocation”, Journal of Machine Learning Research, 3: 993-1022.

Bonilla, T., and Grimmer, J. (2013), “Elevated Threat Levels and Decreased Expectations: How Democracy Handles Terrorist Threats", Poetics, 41: 650-669.

Bourdieu, P. (1986), "The Forms of Capital”, in J.C. Richardson (ed.), Handbook of Theory and Research for the Sociology of Education, Westport, CN: Greenwood Press.

Bourdieu, P. (1990), The Logic of Practice, Cambridge, MA: Harvard University Press.

Bourdieu, P. (1991), Language and Symbolic Power, Cambridge, MA: Harvard University Press.

Cornelissen, J.P., and Werner, M.D. (2014), "Putting Framing in Perspective: A Review of Framing and Frame Analysis across the Management and Organizational Literature", Academy of Management Annals, 8 (1): 181-235.

Czarniawska, B. (1997), Narrating the Organization: Dramas of Institutional Identity, Chicago, IL: University of Chicago Press.

De Cillia, R., Reisigl, M., and Wodak, R. (1999), “The Discursive Construction of National Identities", Discourse \& Society, 10 (2): 149-173.

De Vreese, C.H. (2007), “The EU as a Public Sphere”, Living Reviews in European Governance, 2 (3): $1-22$.

Diez, T. (2001), “Europe as a Discursive Battleground: Discourse Analysis and European Integration Studies", Cooperation and Conflict, 36 (1): 5-38. 
DiMaggio, P., Nag, M., and Blei, D. (2013), “Exploiting Affinities between Topic Modeling and the Sociological Perspective on Culture: Application to Newspaper Coverage of U.S. Government Arts Funding", Poetics, 41: 570-606.

Fairclough, N. (1992), Discourse and Social Change, Cambridge: Polity Press.

Ferri, P., Lusiani, M., and Pareschi, L. (2018), “Accounting for Accounting History: A Topic Modeling Approach (1996-2015)", Accounting History, 23 (1-2): 173-205.

Foucault, M. (1972), The Archeology of Knowledge, Pantheon: London.

Gamson, W., and Modigliani, A. (1989), "Media Discourse and Public Opinion on Nuclear Power: A Constructionist Approach", American Journal of Sociology, 95 (1): 1-37.

Goffman, E. (1974), Frame Analysis: An Essay on the Organization of Experience, London: Harper and Row.

Grimm, D. (1995), “Does Europe Need a Constitution?”, European Law Journal, 1 (3): 282-302.

Habermas, J. (1981), Theorie des kommunikativen Handelns, Frankfurt: Suhrkamp.

Hall, S. (2001), "Foucault: Power, Knowledge and Discourse", in M. Wetherell, S. Taylor and S.J. Yates (eds), Discourse Theory and Practice: A Reader, 72-81, London: SAGE.

Hannigan, T., Haans, R.F.J., Vakili, K., Tchalian, H., Glaser, V., Wang, M., Kaplan, S., and Devereaux Jennings, P. (2019), “Topic Modeling in Management Research: Rendering New Theory from Textual Data", Academy of Management Annals, 13 (2): 586-632.

Hardy, C., and Maguire, S. (2010), "Discourse, Field-Configuring Events, and Change in Organizations and Institutional Fields: Narratives of DDT and the Stockholm Convention", Academy of Management Journal, 53 (6): 1365-1392.

Hardy, C., Palmer, I., and Phillips, N. (2000), “Discourse as a Strategic Resource”, Human Relations, 53 (9): 1227-1248.

Hendry, J. (2000), “Strategic Decision Making, Discourse, and Strategy as Social Practice", Journal of Management Studies, 37 (7): 955-977.

Hooghe, L. (1996), “Reconciling EU-Wide Policy and National Diversity”, in L. Hooghe (ed.), Cohesion Policy and European Integration: Building Multi-Level Governance, 1-24, Oxford: Oxford University Press.

Hooghe, L., and Marks, G. (2001), Multi-Level Governance and European Integration, Lanham, MD: Rowman \& Littlefield.

Hooghe, L., and Marks, G. (2008), "A Postfunctionalist Theory of European Integration: From Permissive Consensus to Constraining Dissensus", British Journal of Political Science, 39 (2): $1-23$.

Janssen, S., Kuipers, G., and Verboord, M. (2008), "Cultural Globalization and Arts Journalism: The International Orientation of Arts and Culture Coverage in Dutch, French, German and U.S. Newspapers, 1955-2005", American Sociological Review, 73: 719-740.

Kantner, C. (2015), “National Media as Transnational Discourse Arenas: The Case of Humanitarian Military Interventions", in T. Risse (ed.), European Public Spheres: Politics Is Back, 84-107, Cambridge: Cambridge University Press.

Koopmans, R., and Erbe, J. (2004), "Towards a European Public Sphere?", Innovation: The European Journal of Social Science Research, 17 (2): 97-118. 
Lelieveldt, H., and Princen, S. (2011), The Politics of the European Union, New York, NY: Cambridge University Press.

Loewenstein, J., Ocasio, W., and Jones, C. (2012), “Vocabularies and Vocabulary Structure: A New Approach Linking Categories, Practices, and Institutions", Academy of Management Annals, 6 (1): 41-86.

McCallum, A.K. (2002), MALLET: A Machine Learning for Language Toolkit. Available online at http://mallet.cs.umass.edu (last accessed: February 28, 2020).

Meyer, R.E., and Höllerer, M.A. (2010), “Meaning Structures in a Contested Issue Field: A Topographic Map of Shareholder Value in Austria", Academy of Management Journal, 53 (6): 1241-1262.

Miller, I.M. (2013), “Rebellion, Crime and Violence in Qing China, 1722-1911: A Topic Modeling Approach", Poetics, 41: 626-649.

Mohr, J.W., and Bogdanov, P. (2013), "Topic Models: What They Are and Why They Matter", Poetics, 41 (6): 545-569.

Mohr, J.W., Wagner-Pacifici, R., Breiger, R.L., and Bogdanov, P. (2013), “Graphing the Grammar of Motives in National Security Strategies: Cultural Interpretation, Automated Text Analysis and the Drama of Global Politics", Poetics, 41: 670-700.

Mollona, E., Aivazidou, E., Barberio, V., Cunico, G., and Pareschi, L. (2019), PERCEIVE project - Deliverable D7.6 'Guidelines on Cohesion Policy Communication'. Available online at http://amsacta.unibo.it/6247/ (last accessed: February 28, 2020). DOI: 10.6092/unibo/amsacta/6247.

Molotch, H., and Lester, M. (1974), "News as Purposive Behavior: On the Strategic Use of Routine Events, Accidents and Scandals", American Sociological Review, 39: 101-112.

Moravcsik, A. (2002), "In Defence of the 'Democratic Deficit'", Journal of Common Market Studies, 40 (4): 603-624.

Ocasio, W., and Joseph., J. (2005), “Cultural Adaptation and Institutional Change: The Evolution of Vocabularies of Corporate Governance, 1972-2003", Poetics, 33: 163-178.

Passi, A. (2001), “Europe as a Social Process and Discourse Considerations of Place, Boundaries and Identity", European Urban and Regional Studies, 8 (1): 7-28.

Phillips, N., Lawrence, T.B., and Hardy, C. (2004), "Discourse and Institutions", Academy of Management Review, 29: 635-652.

Potter, J., and Wetherell, M. (1987), Discourse and Social Psychology: Beyond Attitudes and Behavior, London: SAGE.

Reese, S.D. (1991), "Setting the Media's Agenda: A Power Balance Perspective", Communication Yearbook, 14: 309-340.

Risse, T. (2003), “An Emerging European Public Sphere? Theoretical Clarifications and Empirical Indicators". Paper presented at the Annual Meeting of the European Union Studies Association (EUSA), Nashville, TN, March 27-30.

Risse, T. (2009), "Social Constructivism and European Integration Discursive Approaches", in A. Wiener and T. Diez (eds), European Integration Theory (2 ${ }^{\text {nd }}$ edn.), 144-159, Oxford: Oxford University Press. 
Rhodes C., and Brown, A.D. (2005), "Narrative, Organizations and Research", International Journal of Management Reviews, 7 (3): 167-188.

Trenz, H. (2008), “Understanding Media Impact on European Integration: Enhancing or Restricting the Scope of Legitimacy of the EU?", European Integration, 30 (2): 291-309.

Triga, V., and Vadratsikas, K. (2018), Framing of Cohesion Policy (Cohesify Research Paper 9), Lemesos, Cyprus: Cyprus University of Technology (CUT). Available online at http://www.cohesify.eu/wp-

content/uploads/2018/03/Cohesify_ResearchPaper9_Framing1.pdf (last accessed: February 28, 2020).

Weaver, O. (2009), "Discursive Approaches", in A. Wiener and T. Diez (eds), European Integration Theory (2nd edn.), 163-180, Oxford: Oxford University Press.

Yesilkagit, K., and Blom-Hansen, J. (2007), “Supranational Governance or National Businessas-Usual? The National Administration of EU Structural Funds in the Netherlands and Denmark", Public Administration, 85 (2): 503-524.

Wodak, R., and Krzyżanowski, M. (2017), "Right-Wing Populism in Europe and USA”, Journal of Language and Politics, 16 (4): 471-484. DOI: 10.1075/jlp.17042.krz. 
puntoorg

\section{Appendix A}

40 most important words for each topic

\begin{tabular}{|c|c|c|c|c|c|c|c|c|c|}
\hline \multirow{2}{*}{\multicolumn{2}{|c|}{$\begin{array}{c}0 \\
\text { National Institutions and } \\
\text { European Funds }\end{array}$}} & \multicolumn{2}{|c|}{1} & \multicolumn{2}{|c|}{2} & \multicolumn{2}{|c|}{3} & \multicolumn{2}{|c|}{4} \\
\hline & & \multicolumn{2}{|c|}{ Frauds \& Corruption } & \multicolumn{2}{|c|}{ Jobs \& Development } & \multicolumn{2}{|c|}{ Local institutions } & \multicolumn{2}{|c|}{$\begin{array}{l}\text { Regional policies of southern } \\
\text { regions }\end{array}$} \\
\hline presidente & president & euro & euros & lavoro & work & anni & years & fondi & funds \\
\hline governo & government & formazione & training & governo & government & così & so & campania & campania \\
\hline ministro & minister & milioni & millions & più & more & città & city & sud & south \\
\hline consiglio & council & regione & region & legge & law & più & more & regioni & regions \\
\hline europea & European & corte & court & pubblica & public & provincia & province & più & more \\
\hline premier & premier & corsi & courses & crescita & growth & presidente & president & mezzogiorno & south \\
\hline strutturali & structural & enti & agencies & fiscale & fiscal & mondo & world & caldoro & Caldoro \\
\hline monti & monti & dirigente & leader & pubblico & public & pubblici & public & presidente & president \\
\hline bilancio & balance & assessore & assessor & interventi & interventions & centro & center & europei & Europeans \\
\hline sarà & will & regionale & regional & sociali & social & progetto & project & napoli & Naples \\
\hline imprese & companies & conti & accounts & tempo & time & maggiore & greater & città & city \\
\hline maggioranza & majority & finanziamenti & funding & rapporto & report & commercio & business & puglia & Puglia \\
\hline patto & pact & anni & years & risorse & resources & camera & Parliament & europea & European \\
\hline lombardo & Lombard & giunta & council & politiche & policies & inizio & Start & regionali & regional \\
\hline ministri & Ministers & controlli & controls & riforma & reform & attività & activities & coesione & cohesion \\
\hline settimana & week & dipartimento & department & locali & locals & stati & States & perché & why \\
\hline incontro & meeting & danno & damage & sociale & social & europa & Europe & commissario & commissioner \\
\hline già & already & settore & sector & mesi & months & comune & common & regione & region \\
\hline stato & state & dipendenti & employees & può & can & sarà & will & ministro & minister \\
\hline fondo & fund & guardia & guard & servizi & services & dare & give & politiche & policies \\
\hline
\end{tabular}

PIJ/Volume 5 - Issue 2/2020 
puntoorg

\begin{tabular}{|c|c|c|c|c|c|c|c|c|c|}
\hline \multirow{2}{*}{\multicolumn{2}{|c|}{$\begin{array}{c}0 \\
\text { National Institutions and } \\
\text { European Funds }\end{array}$}} & \multicolumn{2}{|c|}{1} & \multicolumn{2}{|c|}{2} & \multicolumn{2}{|c|}{3} & \multicolumn{2}{|c|}{4} \\
\hline & & \multicolumn{2}{|c|}{ Frauds \& Corruption } & \multicolumn{2}{|c|}{ Jobs \& Development } & \multicolumn{2}{|c|}{ Local institutions } & \multicolumn{2}{|c|}{$\begin{array}{c}\text { Regional policies of southern } \\
\text { regions }\end{array}$} \\
\hline conferenza & conference & mesi & months & obiettivi & targets & ruolo & role & sindaco & mayor \\
\hline presidenza & presidency & sistema & system & nazionale & national & può & can & sviluppo & development \\
\hline tavolo & meeting & finanza & finance & politica & policy & cura & care & progetti & projects \\
\hline tempo & time & crocetta & crocetta & $\begin{array}{l}\text { amministrazi } \\
\text { one }\end{array}$ & $\begin{array}{l}\text { administratio } \\
\mathrm{n}\end{array}$ & messa & done & calabria & calabria \\
\hline stabilità & stability & corso & course & necessario & necessary & centrale & central & roma & Rome \\
\hline misure & measures & palazzo & palace & riduzione & reduction & contro & versus & meridionali & southern \\
\hline contro & versus & anno & year & misure & measures & ricerca & Research & bari & bari \\
\hline riunione & meeting & atti & proceedings & lavoratori & workers & palazzo & palace & politica & policy \\
\hline libera & free & ciapi & CIAPI & aree & areas & agenzia & agency & governo & government \\
\hline giugno & June & frodi & fraud & conti & accounts & futuro & future & patto & pact \\
\hline documento & document & stati & States & mercato & market & conto & bill & programmi & programs \\
\hline c'è & there is & generale & general & effetti & effects & legalità & legality & sindaci & mayors \\
\hline parti & partners & stato & state & livelli & levels & luoghi & places & territoriale & territorial \\
\hline leader & leader & corruzione & corruption & finanziaria & financial & storia & history & johannes & johannes \\
\hline fine & end & russo & Russian & paese & country & priorità & priority & riservata & reserved \\
\hline stampa & press & governatore & governor & economica & economic & migliaia & thousand & aree & areas \\
\hline occupazione & occupation & procura & attorney & situazione & situation & istituzioni & institutions & strategico & strategic \\
\hline palazzo & palace & deputato & deputy & attenzione & caution & grandi & great & riproduzione & reproduction \\
\hline nuovo & new & capo & boss & donne & women & patrimonio & heritage & capacità & capacity \\
\hline berlusconi & berlusconi & $\begin{array}{l}\text { amministrazi } \\
\text { one }\end{array}$ & $\begin{array}{l}\text { administratio } \\
\mathrm{n}\end{array}$ & risultati & results & enti & agencies & importante & important \\
\hline
\end{tabular}

PIJ/Volume 5 - Issue 2/2020 
punt:Oorg

\begin{tabular}{|c|c|c|c|c|c|c|c|c|c|}
\hline \multicolumn{2}{|c|}{5} & \multicolumn{2}{|c|}{6} & \multicolumn{2}{|c|}{7} & \multicolumn{2}{|c|}{8} & \multicolumn{2}{|c|}{9} \\
\hline \multicolumn{2}{|c|}{$\begin{array}{l}\text { Budget of European } \\
\text { Institutions }\end{array}$} & \multicolumn{2}{|c|}{ Education } & \multicolumn{2}{|c|}{ Music Festival } & \multicolumn{2}{|c|}{ European Funds } & \multicolumn{2}{|c|}{ Theatrical Festivals } \\
\hline europea & European & più & more & info & info & fondi & funds & stagione & season \\
\hline commissione & commission & perché & why & bari & bari & milioni & millions & torino & turin \\
\hline più & more & formazione & training & musica & music & euro & EUR & biglietteria & ticket office \\
\hline europeo & European & lavoro & work & $\begin{array}{c}\text { mitosettembre } \\
\text { musica }\end{array}$ & $\begin{array}{l}\text { mitosettembre } \\
\text { musica }\end{array}$ & europea & European & tel & tel \\
\hline l'italia & Italy & giovani & Young people & scena & scene & spesa & expense & biglietti & tickets \\
\hline bilancio & balance & scuola & school & rassegna & review & fondo & fund & abbonamenti & subscriptions \\
\hline paesi & countries & europea & European & serie & series & regione & region & cartelloni & billboards \\
\hline miliardi & billion & sistema & system & programma & program & miliardi & billion & vendita & sale \\
\hline stati & States & attraverso & through & libero & free & progetti & projects & corso & course \\
\hline l'europa & europe & scuole & schools & direttore & director & già & already & festival & festival \\
\hline europa & Europe & legge & law & settembre & september & risorse & resources & piemonte & piedmont \\
\hline italia & Italy & italia & Italy & vittoria & victory & regionale & regional & singoli & single \\
\hline bruxelles & Brussels & competenze & skills & spettacolo & show & europeo & European & prosa & prose \\
\hline membri & membership & livello & level & già & already & anni & years & formazione & training \\
\hline paese & country & nazionale & national & $\begin{array}{c}\text { settembremusic } \\
\text { a }\end{array}$ & $\begin{array}{c}\text { SettembreMusi } \\
\text { ca }\end{array}$ & europei & Europeans & solferino & solferino \\
\hline francia & France & crisi & crisis & disponibili & available & sicilia & sicily & castello & castle \\
\hline juncker & Juncker & centri & centers & laboratori & workshops & sviluppo & development & presso & At \\
\hline europee & European & centro & center & orchestra & orchestra & $\begin{array}{c}\text { programmazio } \\
\text { ne }\end{array}$ & programming & fiore & flower \\
\hline c'è & there is & valutazione & rating & over & over & più & more & verdi & verdi \\
\hline sarà & will be & istruzione & instruction & cittadini & citizens & sociale & social & riapertura & reopening \\
\hline parlamento & parliament & italiana & Italian & sede & seat & stati & States & scena & scene \\
\hline programmi & programs & regione & region & rosa & rose & commissione & commission & cultura & culture \\
\hline
\end{tabular}

PIJ/Volume 5 - Issue 2/2020 
puntoorg

\begin{tabular}{|c|c|c|c|c|c|c|c|c|c|}
\hline \multicolumn{2}{|c|}{5} & \multicolumn{2}{|c|}{6} & \multicolumn{2}{|c|}{7} & \multicolumn{2}{|c|}{8} & \multicolumn{2}{|c|}{9} \\
\hline \multicolumn{2}{|c|}{$\begin{array}{l}\text { Budget of European } \\
\text { Institutions }\end{array}$} & \multicolumn{2}{|c|}{ Education } & \multicolumn{2}{|c|}{ Music Festival } & \multicolumn{2}{|c|}{ European Funds } & \multicolumn{2}{|c|}{ Theatrical Festivals } \\
\hline dell'unione & union & qualità & quality & appuntamento & appointment & unione & Union & classica & classical \\
\hline governi & governments & sociale & social & nizza & nice & lavoro & work & stabile & stable \\
\hline europei & Europeans & problemi & problems & musicale & musical & finanziamenti & funding & all'occhiello & button-hole \\
\hline nazionali & national & risultati & results & edizione & edition & strutturali & structural & compagnia & company \\
\hline commissario & commissioner & obiettivo & target & iscrizioni & inscriptions & soldi & money & scadenza & deadline \\
\hline stato & state & società & society & oro & gold & anno & year & verde & green \\
\hline l'unione & the Union & regioni & regions & auditorium & auditorium & gestione & management & ven & Friday \\
\hline coesione & cohesion & locale & local & gramsci & gramsci & bruxelles & Brussels & rinnovi & renewals \\
\hline vertice & summit & problema & problem & aldo & aldo & regioni & regions & $\begin{array}{l}\text { teatrostabiletor } \\
\text { ino }\end{array}$ & $\begin{array}{c}\text { teatrostabiletor } \\
\text { ino }\end{array}$ \\
\hline renzi & Renzi & importanti & important & auditorium & auditorium & stato & state & prelazione & priority \\
\hline periodo & period & economico & cheap & artisti & artists & grandi & great & scelta & choice \\
\hline stabilità & stability & anno & year & famiglie & families & rischio & risk & orario & schedule \\
\hline barroso & barroso & italiani & Italian & iniziative & initiatives & finanziamento & financing & santibriganti & santibriganti \\
\hline investimenti & investments & europeo & European & iore & iore & regionali & regional & aperta & open \\
\hline strutturali & structural & famiglie & families & infonica & infonica & politiche & policies & riposo & rest \\
\hline posto & place & tempo & time & rai & rai & fine & end & corsi & courses \\
\hline dell'europa & europe & nuove & new & $\begin{array}{c}\text { teatromonteros } \\
\mathrm{a}\end{array}$ & $\begin{array}{c}\text { teatromonteros } \\
\mathrm{a}\end{array}$ & destinati & intended & guardie & guards \\
\hline nuovo & new & scolastico & school & ribalta & limelight & però & However & tst & tst \\
\hline
\end{tabular}

\begin{tabular}{|c|c|c|c|c|c|c|c|c|c|}
\hline \multicolumn{2}{|c|}{10} & \multicolumn{2}{|c|}{11} & \multicolumn{2}{|c|}{12} & \multicolumn{2}{|c|}{13} & \multicolumn{2}{|c|}{14} \\
\hline \multicolumn{2}{|c|}{ Theatrical Classes } & \multicolumn{2}{|c|}{ Emergency } & \multicolumn{2}{|c|}{$\begin{array}{l}\text { Cohesion policies for } \\
\text { entrepreneurship }\end{array}$} & \multicolumn{2}{|c|}{ Macroeconomics } & \multicolumn{2}{|c|}{ Invitations to tender } \\
\hline corso & course & rifiuti & waste & più & more & crescita & growth & euro & euros \\
\hline
\end{tabular}

PIJ/Volume 5 - Issue 2/2020 
puntoorg

\begin{tabular}{|c|c|c|c|c|c|c|c|c|c|}
\hline \multicolumn{2}{|c|}{10} & \multicolumn{2}{|c|}{11} & \multicolumn{2}{|c|}{12} & \multicolumn{2}{|c|}{13} & \multicolumn{2}{|c|}{14} \\
\hline \multicolumn{2}{|c|}{ Theatrical Classes } & \multicolumn{2}{|c|}{ Emergency } & \multicolumn{2}{|c|}{$\begin{array}{l}\text { Cohesion policies for } \\
\text { entrepreneurship }\end{array}$} & \multicolumn{2}{|c|}{ Macroeconomics } & \multicolumn{2}{|c|}{ Invitations to tender } \\
\hline stagione & season & protezione & protection & imprese & companies & più & more & progetto & project \\
\hline vendita & sale & civile & civil & puglia & Puglia & crisi & crisis & stato & state \\
\hline abbonamenti & subscriptions & cittadini & citizens & sviluppo & development & miliardi & billion & lavori & works \\
\hline ragazzi & boys & solidarietà & solidarity & ricerca & Research & debito & debt & bando & ban \\
\hline rassegna & review & impianti & installations & anni & years & riforme & reforms & pompei & pompei \\
\hline corsi & courses & comuni & common & sistema & system & paesi & countries & gara & bid \\
\hline aperte & open & regione & region & perché & why & banche & banks & sarà & will \\
\hline bambini & children & situazione & situation & settore & sector & grecia & Greece & realizzazione & realization \\
\hline tst & tst & emergenza & emergency & crisi & crisis & investimenti & investments & generale & general \\
\hline scelta & choice & provincia & province & aziende & companies & germania & Germany & sito & place \\
\hline biglietti & tickets & discariche & landfill & investimenti & investments & politica & policy & ministero & ministry \\
\hline biglietteria & ticket office & sindaco & mayor & innovazione & innovation & banca & bank & direzione & direction \\
\hline tel & tel & strade & roads & energia & power & economica & economic & bandi & auction \\
\hline anni & years & danni & damage & regione & region & merkel & merkel & società & society \\
\hline verdi & verdi & perché & why & più & more & stato & state & opere & works \\
\hline p.za & p.za & napoli & Naples & regionale & regional & mercati & markets & culturali & cultural \\
\hline carignano & carignano & territorio & territory & italia & Italy & paese & country & opera & Opera \\
\hline vedi & you see & napolitano & napolitano & sarà & will & bisogno & need & area & area \\
\hline scuola & school & commissario & commissioner & settori & sectors & euro & EUR & personale & staff \\
\hline campagna & campaign & centro & center & infrastrutture & infrastructure & disoccupazione & unemployment & rete & network \\
\hline festival & festival & colpite & affected & piccole & small & comune & common & responsabile & responsible \\
\hline adulti & adults & tonnellate & tons & economia & economy & politiche & policies & sicurezza & safety \\
\hline castello & castle & ambiente & environment & però & However & mercato & market & entro & within \\
\hline
\end{tabular}


punt(Oorg

\begin{tabular}{|c|c|c|c|c|c|c|c|c|c|}
\hline \multicolumn{2}{|c|}{10} & \multicolumn{2}{|c|}{11} & \multicolumn{2}{|c|}{12} & \multicolumn{2}{|c|}{13} & \multicolumn{2}{|c|}{14} \\
\hline \multicolumn{2}{|c|}{ Theatrical Classes } & \multicolumn{2}{|c|}{ Emergency } & \multicolumn{2}{|c|}{$\begin{array}{l}\text { Cohesion policies for } \\
\text { entrepreneurship }\end{array}$} & \multicolumn{2}{|c|}{ Macroeconomics } & \multicolumn{2}{|c|}{ Invitations to tender } \\
\hline piemontese & piedmontese & ricostruzione & reconstruction & problema & problem & competitività & $\begin{array}{c}\text { competitivenes } \\
\mathrm{s}\end{array}$ & gestione & management \\
\hline $\begin{array}{c}\text { www.teatrosta } \\
\text { biletorino.it }\end{array}$ & $\begin{array}{c}\text { www.teatrosta } \\
\text { biletorino.it }\end{array}$ & politica & policy & presidente & president & pubblici & public & corso & course \\
\hline scena & scene & assessore & assessor & stato & state & unione & Union & attività & activities \\
\hline torino & turin & propria & own & produzione & production & rigore & strictness & soggetti & subjects \\
\hline torinodanza & Torinodanza & potere & power & creare & create & europei & Europeans & direttore & director \\
\hline iscrizioni & inscriptions & chilometri & kilometres & ciò & it & fine & end & servizi & services \\
\hline spettacolo & show & voglia & wish & territorio & territory & misure & measures & napoli & Naples \\
\hline formazione & training & casa & home & industriale & industrial & bei & beautiful & beni & goods \\
\hline abbonamento & subscription & raccolta & collection & mondo & world & recessione & recession & mostra & exhibition \\
\hline moncalieri & moncalieri & campania & campania & progetto & project & finanziaria & financial & bagnoli & bagnoli \\
\hline singoli & single & zona & area & economico & cheap & investitori & investors & anni & years \\
\hline anno & year & popolazioni & populations & qualità & quality & capitale & capital & conclusione & conclusion \\
\hline libero & free & nessuno & nobody & strutturali & structural & finanze & finances & speciale & special \\
\hline presentazione & presentation & antonio & antonio & nuove & new & stati & States & partecipazione & participation \\
\hline domani & tomorrow & sociale & social & attività & activities & tedesca & German & presentazione & presentation \\
\hline piemonte & piedmont & anni & years & piemonte & piedmont & finanziarie & financial & ferroviaria & train \\
\hline
\end{tabular}

